\title{
Moloney Sarcoma Virus
}

National Cancer Institute

\section{Source}

National Cancer Institute. Moloney Sarcoma Virus. NCI Thesaurus. Code C14242.

A positive sense, single-stranded RNA (sSRNA), replication-defective retrovirus species belong ing to the Gammaretrovirus genus. It is a causitive agent for sarcomas in mice and other mammals. 